\title{
Innovative Survey on Dual Fuel Engine with Fuel Essences
}

\author{
Kirubadurai B. ${ }^{1, ~}$, Suresh Kumar K. ${ }^{1}$, Dinesh G. ${ }^{1}$, Faseehur Rahman S. \\ ${ }^{1}$ Mechatronics Department, Er. Perumal Manimekalai College of Engineering, Hosur, Tamilnadu, India \\ ${ }^{2}$ Aeronautical Department, Er. Perumal Manimekalai College of Engineering, Hosur, Tamilnadu, India
}

\section{Email address:}

bkirubadurai@gmail.com (Kirubadurai B.), rakkismart90@gmail.com (Faseehur R. S.)

${ }^{*}$ Corresponding author

\section{To cite this article:}

Kirubadurai B., Suresh Kumar K., Dinesh G., Faseehur Rahman S. Innovative Survey on Dual Fuel Engine with Fuel Essences. International Journal of High Energy Physics. Vol. 4, No. 1, 2017, pp. 1-11. doi: 10.11648/j.jhep.20170401.11

Received: January 18, 2017; Accepted: January 31, 2017; Published: March 28, 2017

\begin{abstract}
Alternative fuels have been getting more attention as concerns escalate over exhaust pollutant emissions produced by internal combustion engines, higher fuel costs, and the depletion of crude oil. Various solutions have been proposed, including utilizing alternative fuels as a dedicated fuel in spark ignited engines, diesel pilot ignition engines, gas turbines, and dual fuel and bi-fuel engines. Among these applications, one of the most promising options is the diesel derivative dual fuel engine with natural gas as the supplement fuel. This study aims to evaluate diesel and dual fuel combustion in a di ethyl eaterdiesel dual fuel engine. More dual fuel engines are being utilized due to stricter emission standards, increasing costs of diesel fuel and decreasing costs of di ethyl eater. Originally sold as diesel engines, these units are converted to di ethyl eater-diesel fuel engines using an aftermarket dual fuel kit. As di ethyl eater is mixed with diesel, the amount of diesel used is reduced. The maximum di ethyl eater substitution is limited by knock or emissions of carbon monoxide and total hydrocarbons.
\end{abstract}

Keywords: Alternative Fuels, Di Ethyl Eater-Diesel Dual Fuel, Emissions, Hydrocarbons

\section{Introduction}

The Spark-ignition and diesel engines in today's automobiles contribute to the urban air pollution problem. Oxide of nitrogen, hydrocarbons, carbon monoxide and carbon dioxide are formed in the combustion chambers of these engines and are emitted into the atmosphere. The importance on controlling emissions from automobiles while improving fuel economy has increased a substantial research and development effort in pollution control. As a result, control technology and the understanding of pollutant formation mechanisms have developed rapidly during the past decade.

To meet diesel vehicular exhaust emission norms worldwide, several exhaust pretreatment and post treatment technique have been employed in diesel engine. This project aims the experimental investigation on performance and emission characteristics of a single cylinder, four stroke direct injection diesel engine. A counter flow heat exchanger arrangement was provided for obtaining preheating and pre heating with exhaust gas recirculation. The performance parameters were studied with preheating, exhaust gas recirculation and preheating with exhaust gas recirculation, which are being used widely to reduce and controls the oxides of nitrogen emission (NOx) from diesel engine.

In this investigation, experimental studies are made to clarify the effects of EGR, pre heating and EGR with preheating on combustion and emissions of a diesel engine.

\section{Exhaust Gas Recirculation}

Exhaust Gas Recirculation is an effective method for $\mathrm{NO}_{\mathrm{x}}$ control. The exhaust gases mainly consist of carbon dioxide $\left(\mathrm{CO}_{2}\right)$, water vapour $\left(\mathrm{H}_{2} \mathrm{O}\right)$, nitrogen $\left(\mathrm{N}_{2}\right)$, and oxygen $\left(\mathrm{O}_{2}\right)$; carbon monoxide (CO), hydrocarbons $(\mathrm{HC})$, oxides of nitrogen $\left(\mathrm{NO}_{\mathrm{x}}\right)$, and particulate matter $(\mathrm{PM})$ are present in significant quantities. The mixture has higher specific heat compared to atmospheric air. Re-circulated exhaust gas displaces fresh air entering the combustion chamber. As a consequence of this air displacement, lower amount of oxygen in the intake mixture is available for combustion. Reduced oxygen available for combustion lowers the effective air-fuel ratio.

This effective reduction in air-fuel ratio affects exhaust 
emissions substantially. The mixing of exhaust gases with intake air increases specific heat of intake mixture, which results in the reduction of flame temperature. Thus combination of lower oxygen quantity in the intake air and reduced flame temperature reduces rate of NOx formation reactions. The EGR (\%) is defined as the mass percent of the re-circulated exhaust in the total intake mixture.

$$
\begin{aligned}
& \text { EGR \% }=\frac{\text { Mass of exhaust gas re circulated }}{\text { Mass of inlet }} \\
& \text { EGR \% }=\frac{\text { Mass of exhaust gas re circulated }}{\text { Mass of fuel }+ \text { mass of air }}
\end{aligned}
$$

The engines using EGR emit lower quantity of $\mathrm{NO}_{\mathrm{x}}$ compared to non-EGR engines because part of the exhaust gas is re-circulated. Thus even if the concentration of toxic substances in the exhaust gas remains unchanged, the total quantity of emission of toxic substances reduce for the same volumetric concentration.

Diesel engines operating at low Loads and generally tolerate a higher EGR ratio because re-circulating exhaust gases contain high concentration of oxygen and low concentration of carbon dioxide and water vapours. However at higher Loads, the oxygen in exhaust gas becomes scarce and the inert constituents start dominating with increased exhaust temperature. Thus, as Load increases, diesel engines tend to generate more smoke because of reduced availability of oxygen.

Combined Effect of Inlet Air Preheating With EGR

This investigation mainly focuses on reducing exhaust emission and energy saving by investigating diesel combustion with neat diesel fuel and a new attachment of inlet air preheated with Exhaust Gas Recirculation system. Experiment was conducted in a four stroke naturally aspirated diesel engine with inlet air preheating attachment and EGR system. Inlet air preheating and EGR were applied to the experimental engine separately and also together to observe their effects on engine performance. In this study, engine exhaust gas temperature was used to preheat the inlet air passing through a newly designed air preheating system. In inlet air preheating attachment, a counter flow heat exchanger was used to transfer heat from exhaust gases to inlet air. It was found that combined effect of inlet air preheating attachment and EGR system provided better result on engine performance than individual effect. It was found that at medium Load conditions, oxides of nitrogen, carbon monoxide, engine noise, and brake specific fuel consumption decreased when inlet air preheating and EGR were applied together as compared to those during normal operations of the engine.

Table 1. Engine Specification.

\begin{tabular}{ll}
\hline Type & $\begin{array}{l}\text { Single cylinder, vertical, four stroke } \\
\text { cycle, water cooled, compression ignition } \\
\text { diesel engine (TEXVEL ENGINE) }\end{array}$ \\
\hline Bore in mm & 85 \\
Stroke length in mm & 110 \\
Rated power in kW & 6.5 \\
Loading & Rope brake \\
Connecting rod length in mm & 235 \\
Compression ratio & $18: 1$ \\
Inlet valve open & $4^{\circ}$ before TDC \\
Inlet valve close & $40^{\circ}$ after BDC \\
Exhaust valve open & $38^{\circ}$ before BDC \\
Exhaust valve close & $18^{\circ}$ after TDC \\
Fuel injection starts & $18^{\circ}$ before TDC \\
Fuel injection ends & $27^{\circ}$ after TDC \\
Valve overlap & 0.00249 sec \\
Rated speed & 1500 rpm \\
Number of nozzle holes & 3 holes \\
Fuel injection pressure & 180 bar \\
\hline
\end{tabular}

\section{Experimental Setup}

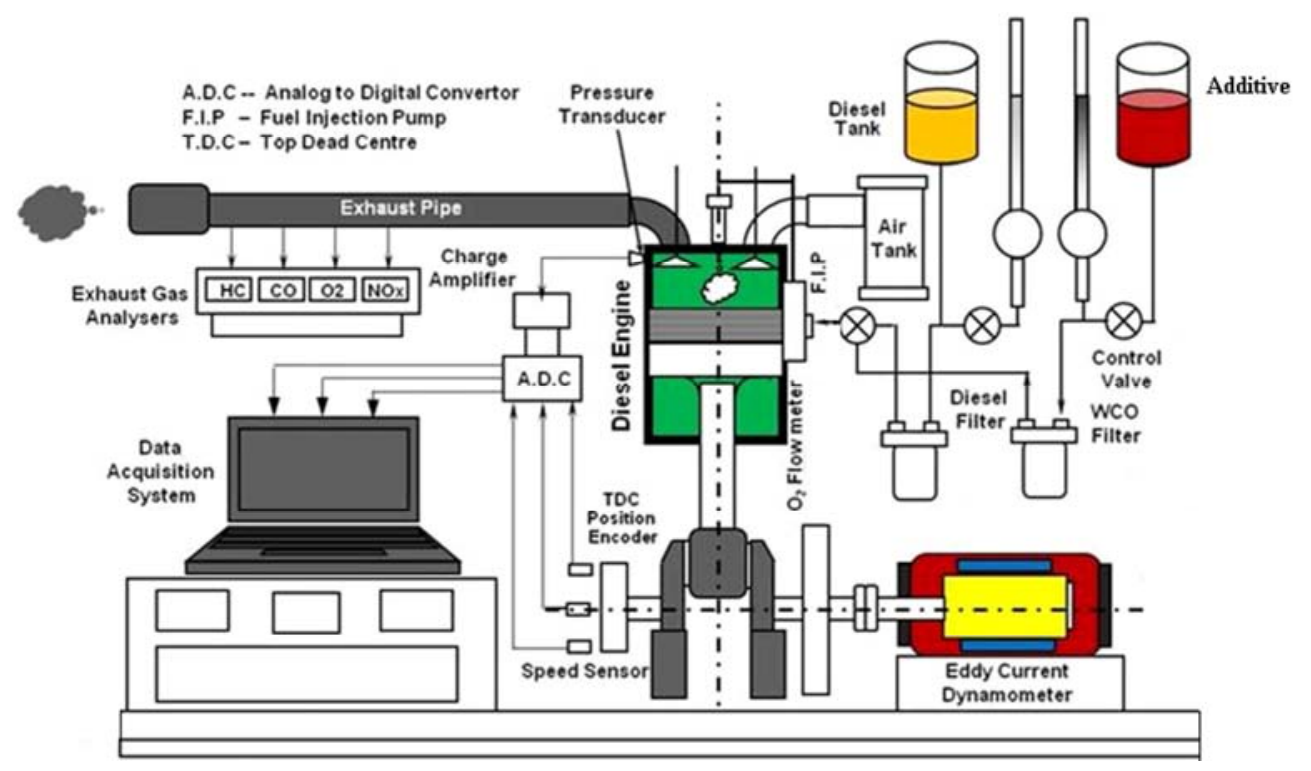

Figure 1. Experimental setup. 
This experimental test conducted in single cylinder, direct injection, water cooled, compression ignition engine. This experimental setup is shown in figure 1. The mass flow rate of the inlet charge and EGR percentage were obtained by utube manometer. The preheating and EGR with preheating was done by counter flow heat exchanger. The EGR system was achieved by taking the exhaust gas from the exhaust pipe.

The amount of exhaust gas recycling with inlet charge was controlled by exhaust control valve. The three thermometers were installed to measure inlet charge temperature, exhaust gas temperature before recycling and exhaust gas temperature after recycling. The probe of exhaust gas analyser is inserted into the exhaust pipe for emission measurement. The engine is loaded with rope brake dynamometer. The required readings were taken by varying the engine Load.

\section{Experimental Procedure}

Initially the engine was started by cranking and the de compression lever was used for easy cranking.

- The engine is allowed to run and attain the steady state.

- The Load is applied in $\mathrm{kg}$ at each Load the time taken for $25 \mathrm{cc}$ of fuel consumption is noted down.

- Governor adjustment is used to maintain the constant speed of the engine at each Load

Exhaust Gas Analyser

Table 2. Exhaust Gas Analyser Specification.

\begin{tabular}{llll}
\hline Parameter & Resolution & Accuracy & Range \\
\hline Oxygen & $0.1 \%$ & $\pm 0.2 \%$ & $0-21 \%$ \\
Carbon Monoxide & $1 \mathrm{ppm}, \mathrm{mg} / \mathrm{m}^{3}$ & $\pm 20 \mathrm{ppm}<400 \mathrm{ppm}$ & $0-4000 \mathrm{ppm}$, \\
& & $\pm 5 \%>400 \mathrm{ppm}$ & $0-5000 \mathrm{mg} / \mathrm{m}^{3}$ \\
Nitric Oxide (optional & $1 \mathrm{ppm}, \mathrm{mg} / \mathrm{m}^{3}$ & $\pm 5 \mathrm{ppm}<100 \mathrm{ppm}$ & $0-5000 \mathrm{ppm}$, \\
& & $\pm 5 \%>100 \mathrm{ppm}$ & $0-6700 \mathrm{mg} / \mathrm{m}^{3}$ \\
Nitrogen Dioxide (optional) & $1 \mathrm{ppm}, \mathrm{mg} / \mathrm{m}^{3}$ & $\pm 5 \%$ full scale & $100 \mathrm{ppm}, 200 \mathrm{mg} / \mathrm{m}^{3}$ \\
Carbon Dioxide & $0.1 \%$ & $\pm 0.3 \%$ reading & $0-99.9^{3}$ \\
CO/CO $\mathrm{CO}_{2}$ ratio & 0.0001 & \pm 0.0001 & $0-0.9999$ \\
Carbon Monoxide, $\mathrm{H}_{2}$ compensated & $1 \mathrm{ppm}, \mathrm{mg} / \mathrm{m}^{3}$ & $\pm 20 \mathrm{ppm}<400 \mathrm{ppm}$ & $0-10,000 \mathrm{ppm}$, \\
& & $\pm 5 \%<5000 \mathrm{ppm}$ & $0-12,000 \mathrm{mg} / \mathrm{m}^{3}$ \\
& & & $0-600^{\circ} \mathrm{C} / 32-1112^{\circ} \mathrm{F}$ \\
Temp (Nett) & $1.0^{\circ} \mathrm{C} / \mathrm{F}$ & $\pm 10 \%>5000 \mathrm{ppm}$ & $0-5000 \mathrm{ppm}$ \\
& & $\pm 2^{\circ} \mathrm{C} \pm 0.3 \%$ reading & $0 v e r-\mathrm{range}$ \\
Hydro carbon & $1 \mathrm{ppm}$ & $\pm 5 \%$ of reading & $10000 \mathrm{ppm}$ \\
\end{tabular}

The KANE 900 plus emission analyser has been adopted, it to be used for petrol, LPG and diesel powered vehicles. It can measure carbon monoxide, oxygen, oxides of nitrogen $\left(\mathrm{NO}_{\mathrm{x}}\right)$, and unburned hydro carbons.

\section{Result and Discussion}

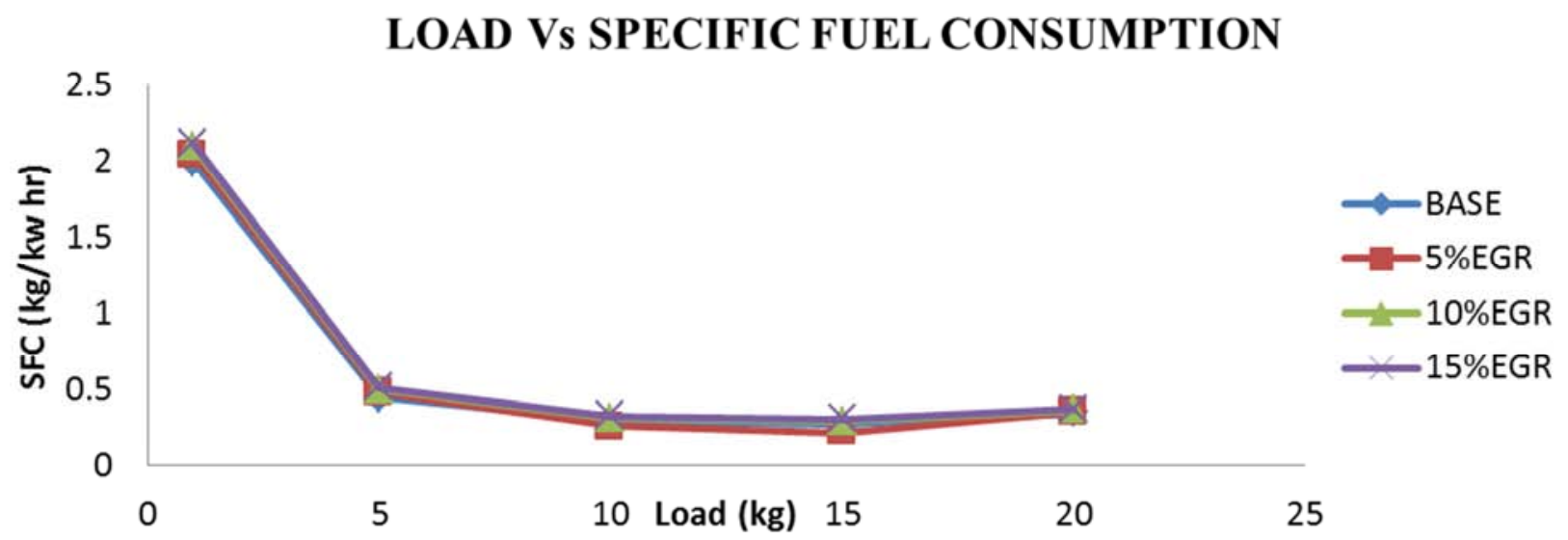

Figure 2. Load Vs Specific Fuel Consumption for EGR.

Figure 2 represents comparison of specific fuel consumption with load for EGR and base line data. The brake specific fuel consumption for 5\% EGR is found to be decreased. when compard to base line data the specific fuel consumption for other EGR is increased. 


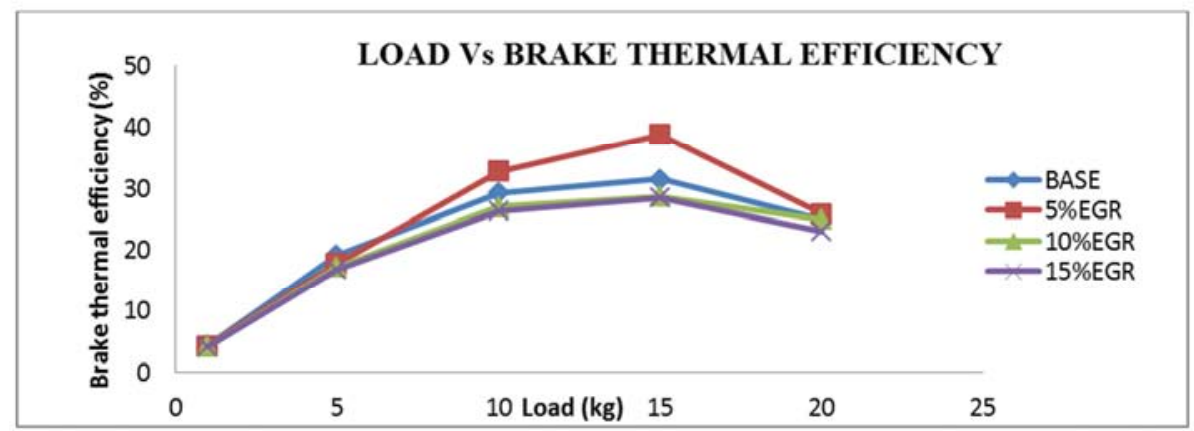

Figure 3. Load Vs brake thermal efficiency for EGR.

Figure 3 shows that when the load increased the thermal efficiency is found to be increased for 5\% EGR. The possible reason for increasing thermal efficiency at 5\% EGR is re burning of hydro carbons may be occured while using the exhaust gas recirculation system. Thermal efficiency is found to be decreased for other EGR percentage when compard to with out EGR.

\section{Load Vs ฤCOMBUSTION}

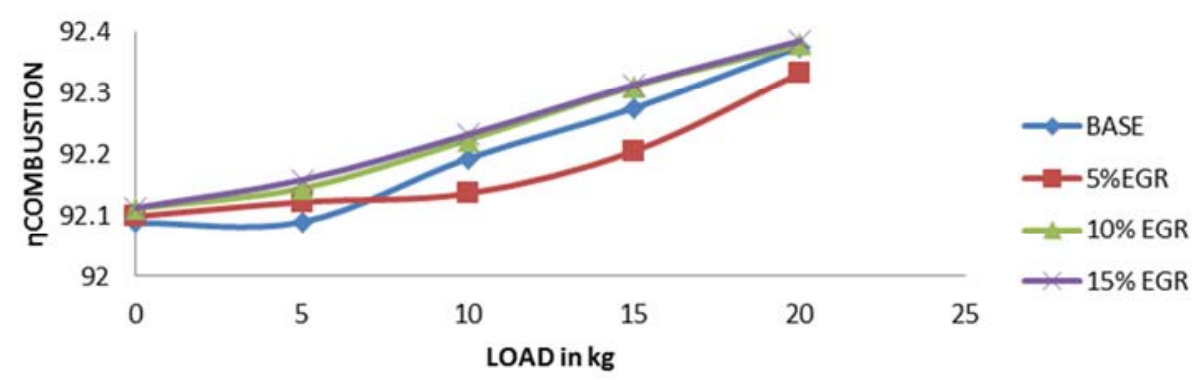

Figure 4. Load Vs Combustion Efficiency For EGR.

Figure 4 represents variation of combustion efficiency with engine load for different EGR percentage. The combustion efficiency is found to be high for all loads when using 10\% EGR and 20\% EGR when compared to base line data and 15\% EGR.

\section{EMISSION GRAPH FOR EGR}

\section{LOAD Vs CO\%}

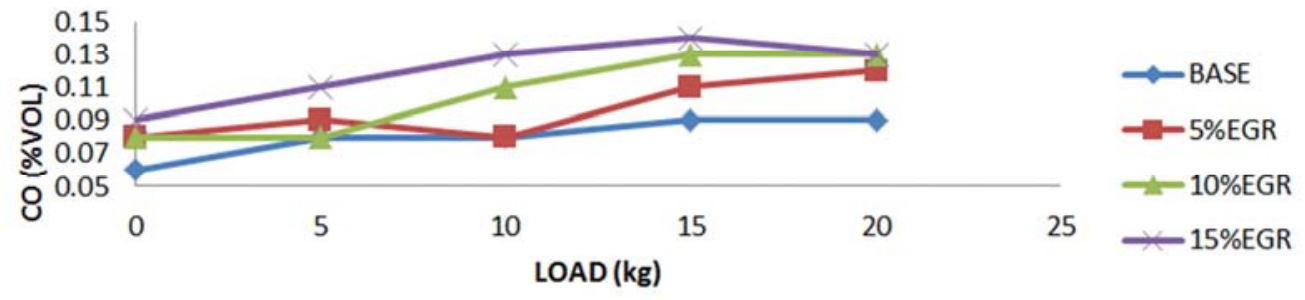

Figure 5. Load VS Carbon Monoxide Emission (CO) For EGR.

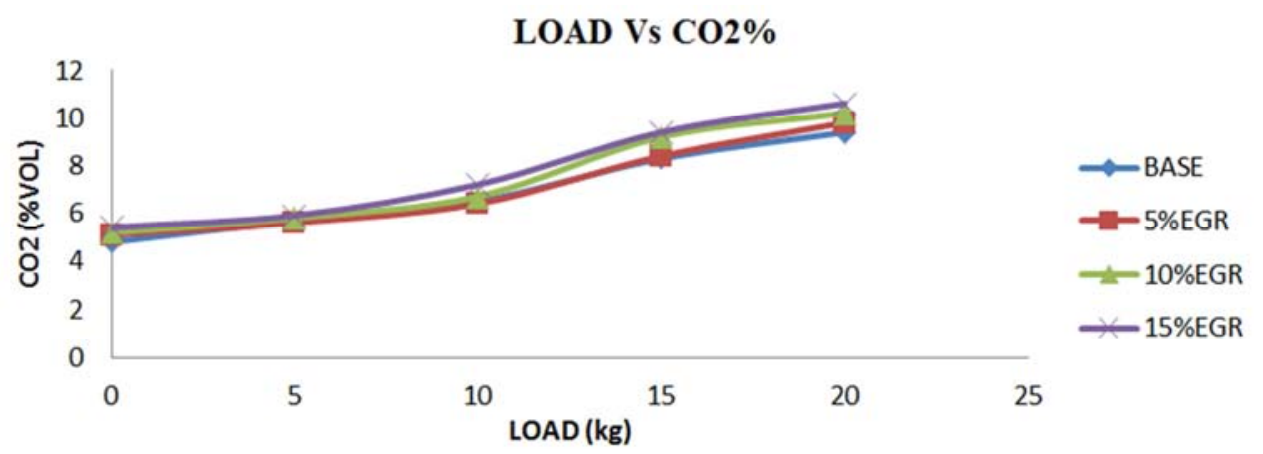

Figure 6. Load Vs carbon dioxide emission $\left(\mathrm{CO}_{2}\right)$ for $E G R$. 


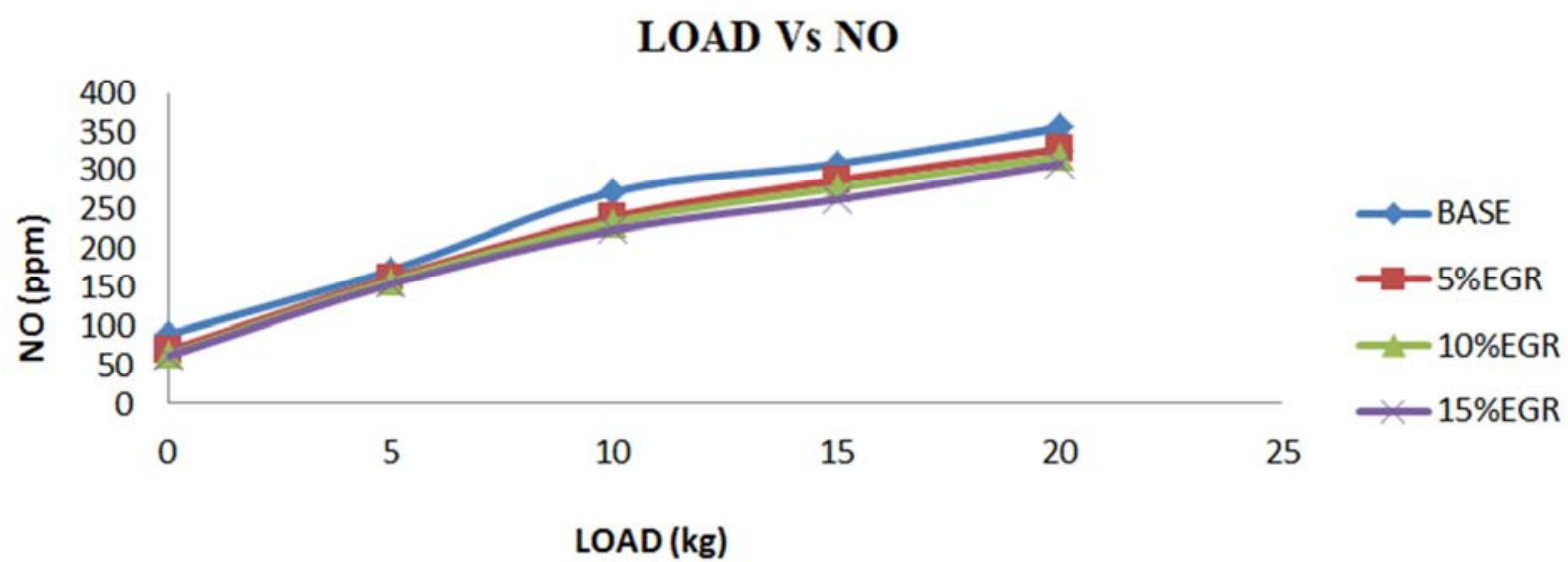

Figure 7. Load Vs Nitric oxide (NO) for EGR.

\section{LOAD Vs NOx}

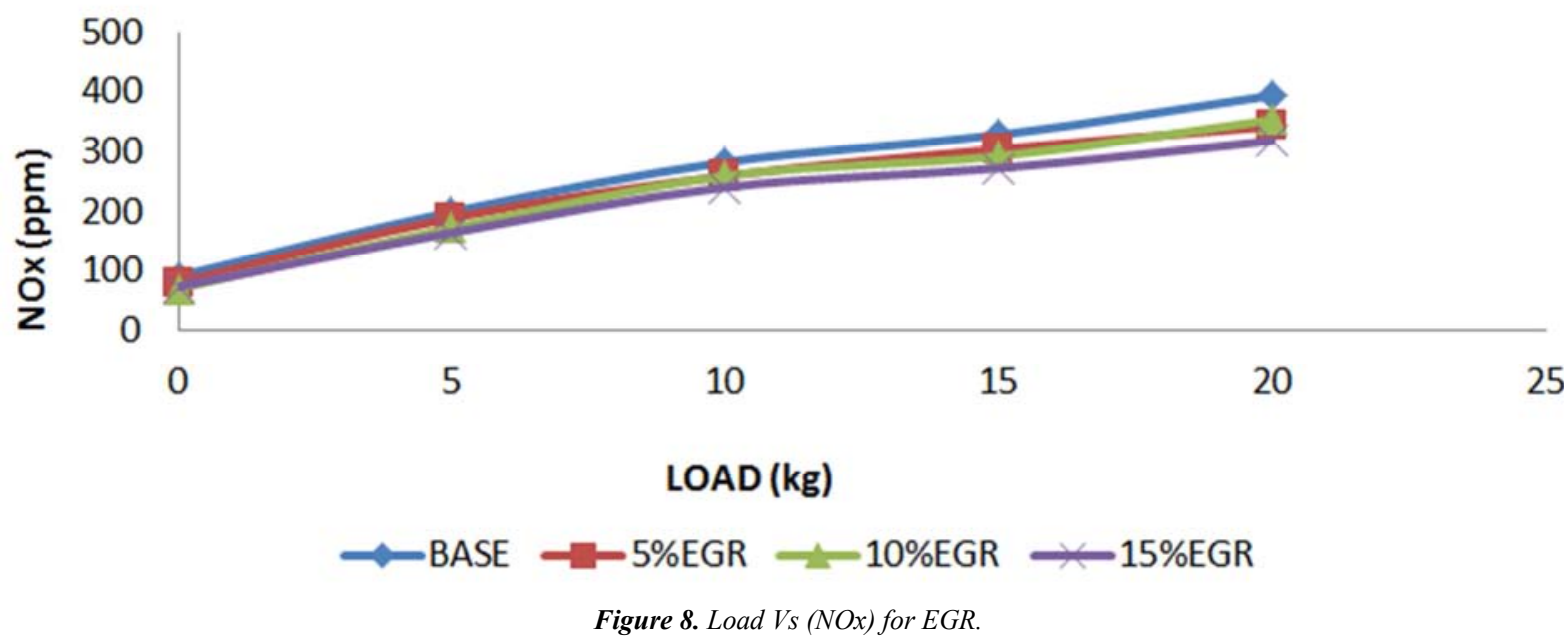

Figure 5 and 6 shows that by using EGR the $\mathrm{CO}$ and $\mathrm{CO}_{2}$ formation are found to be increased when compard to base line data.

Fig. 8 shows the main benefit of EGR in reducing $\mathrm{NO}_{\mathrm{X}}$ emission from diesel engine. The degree of reduction of $\mathrm{NO}_{\mathrm{X}}$ is high while using more EGR percentage.

PERFORMANCE GRAPH FOR PRE HEATING

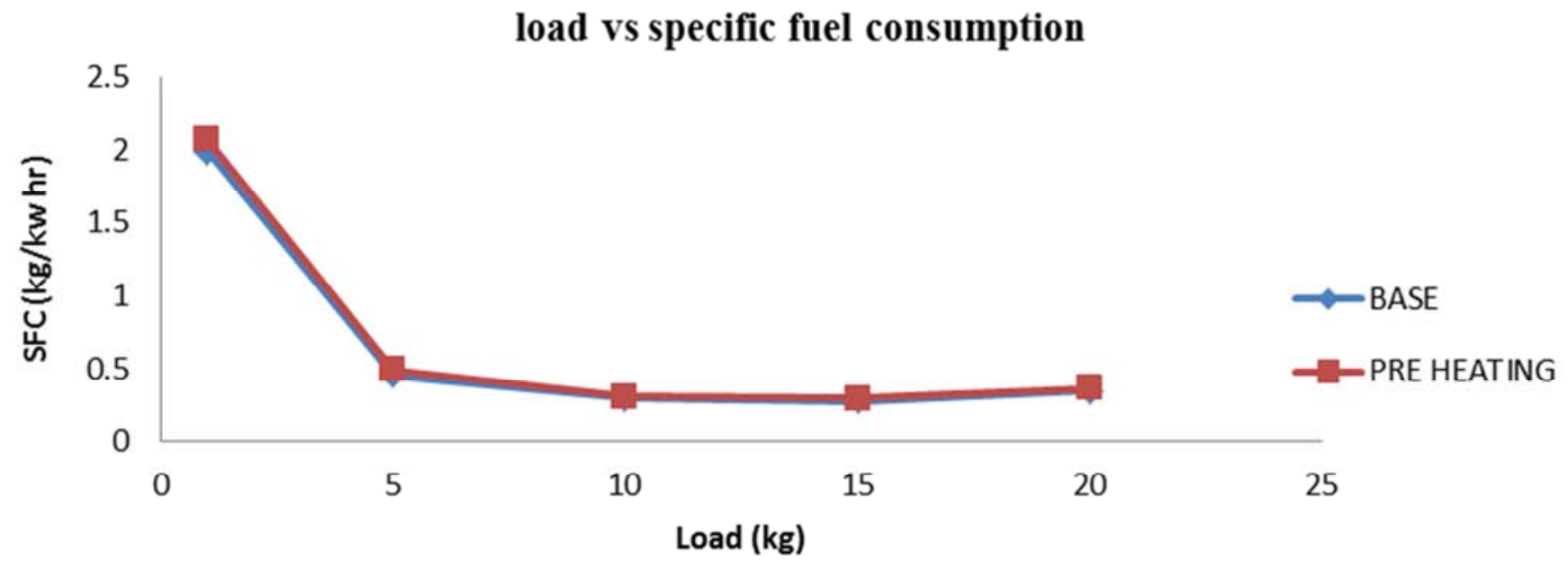

Figure 9. Load Vs Specific Fuel Consumption For Pre Heating. 


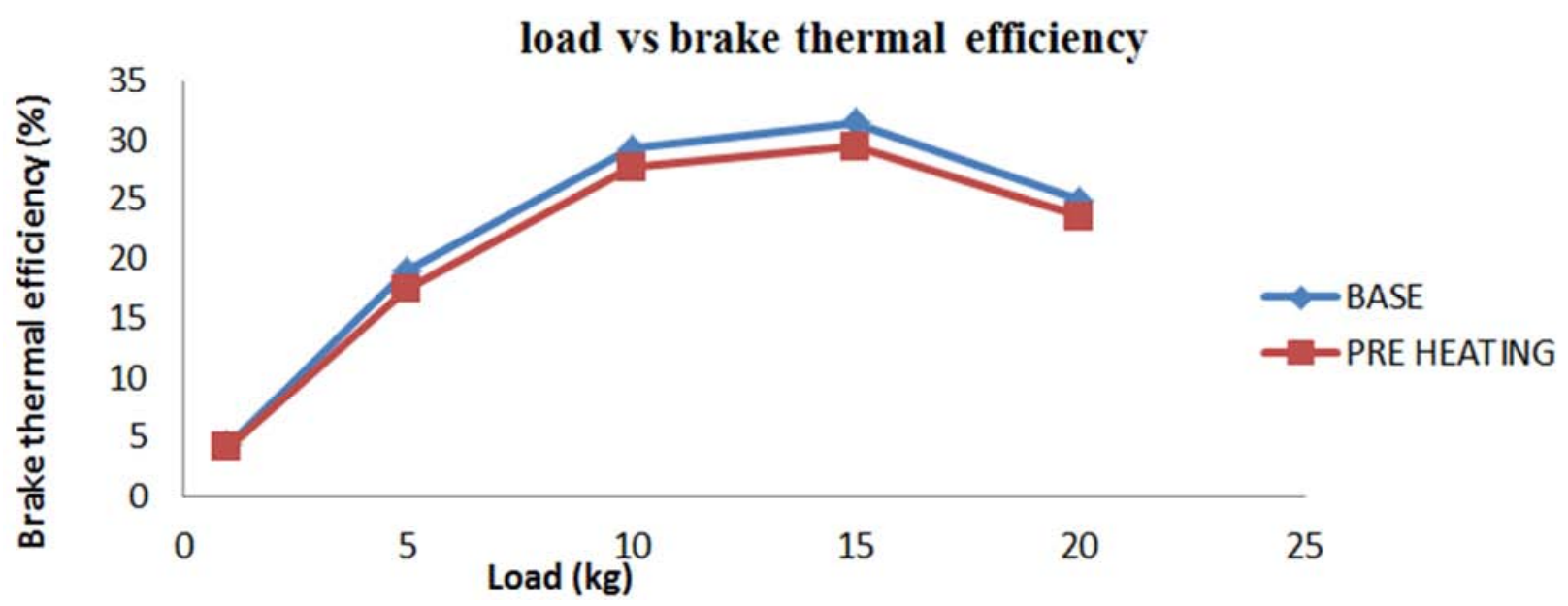

Figure 10. Load Vs Brake thermal efficiency for pre heating.

\section{load vs qcombustion}

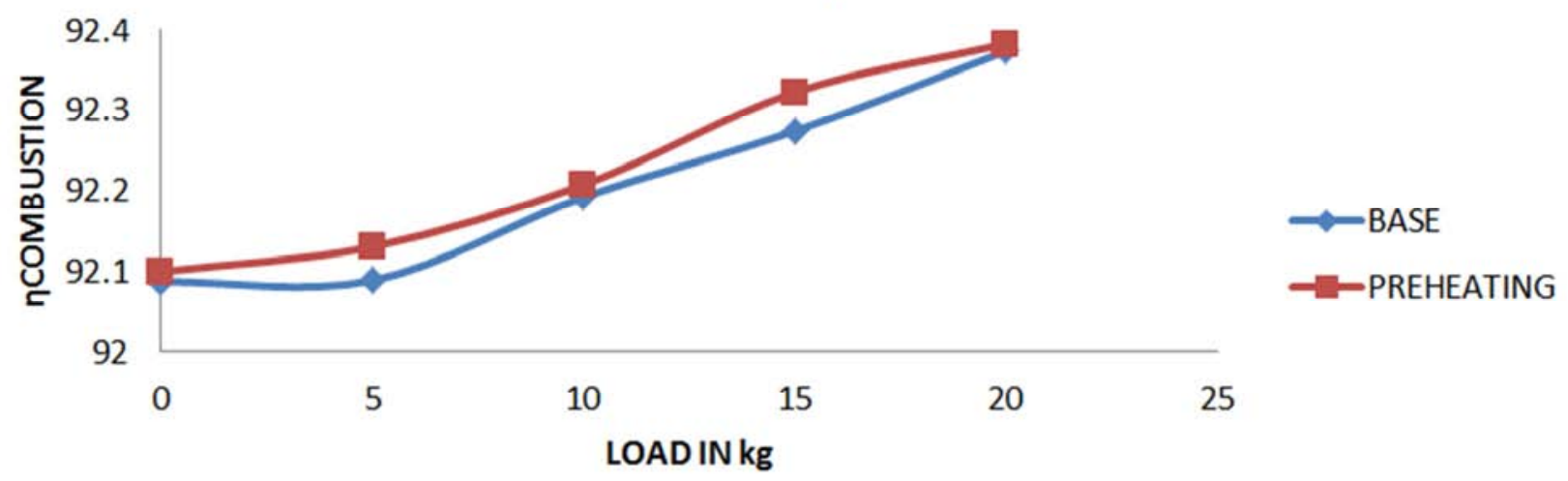

Figure 11. Load VS Combustion efficiency for pre heating.

Figures 9 and 10 are shows that the th specific fuel consumption is found to be increased and thermal efficiency is decreased when pre heating the inlet air.

Figure 11 represents When pre heating the inlet air the combustion efficiency is increased for all loads

EMISSION GRAPH FOR PRE HEATING

\section{LOAD Vs CO\%}

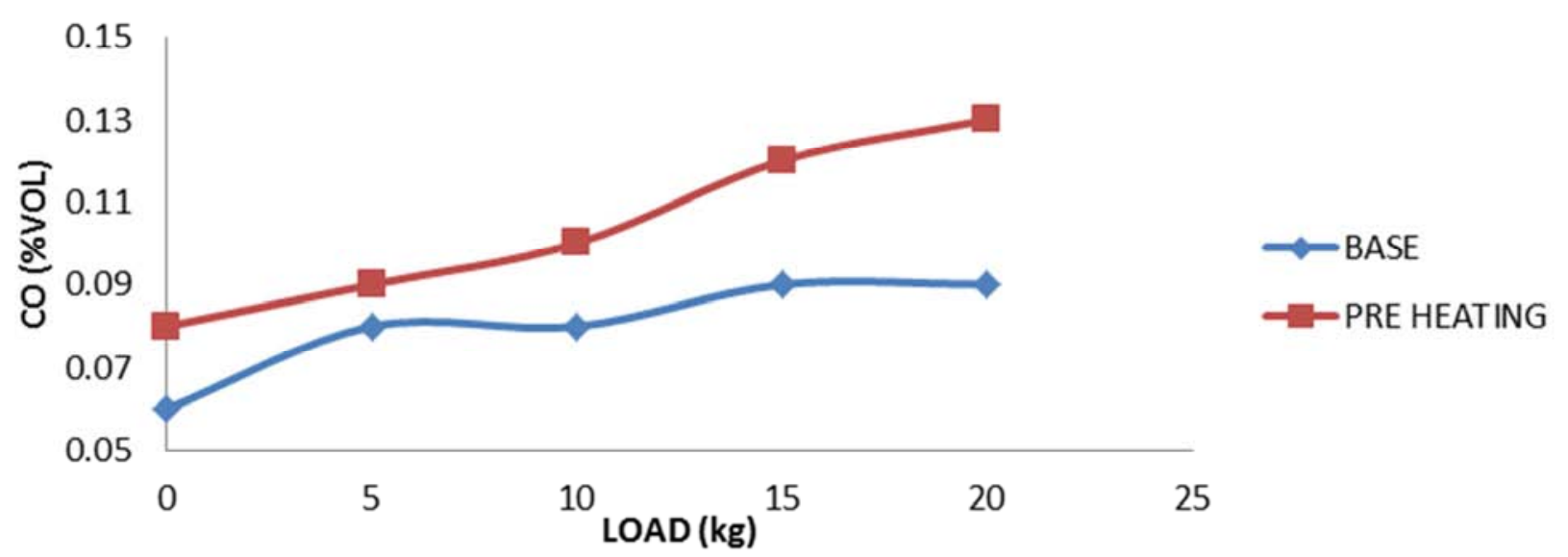

Figure 12. Load Vs Carbon Monoxide Emission (CO) for Pre Heating. 


\section{LOAD Vs CO2\%}

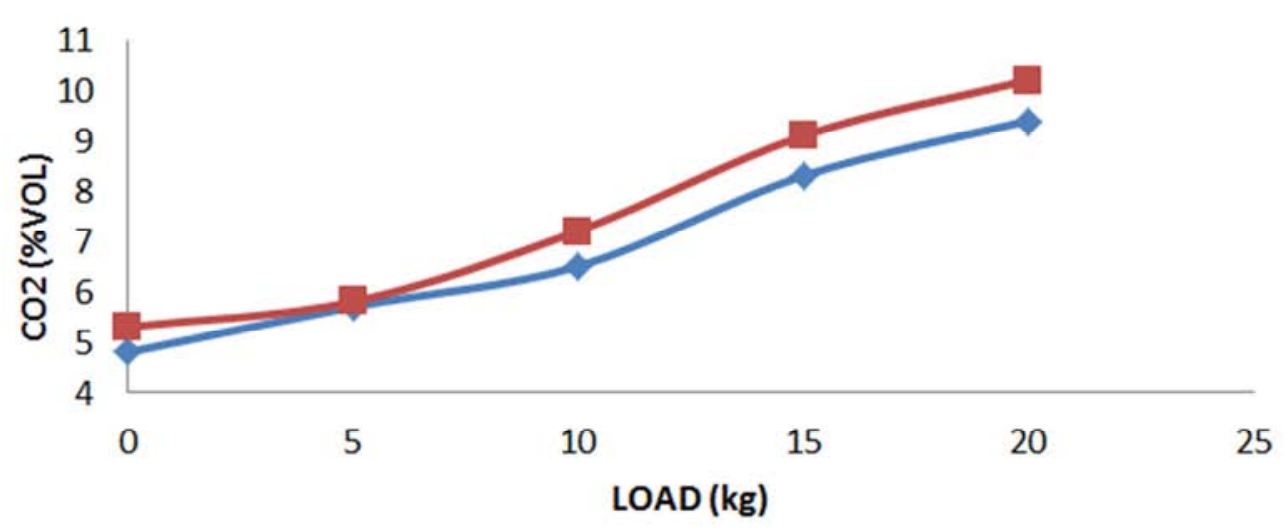

$\leadsto$ BASE

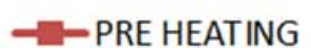

Figure 13. Load VS Carbon Dioxide Emission $\left(\mathrm{CO}_{2}\right)$ for Pre Heating.

\section{LOAD Vs NO}

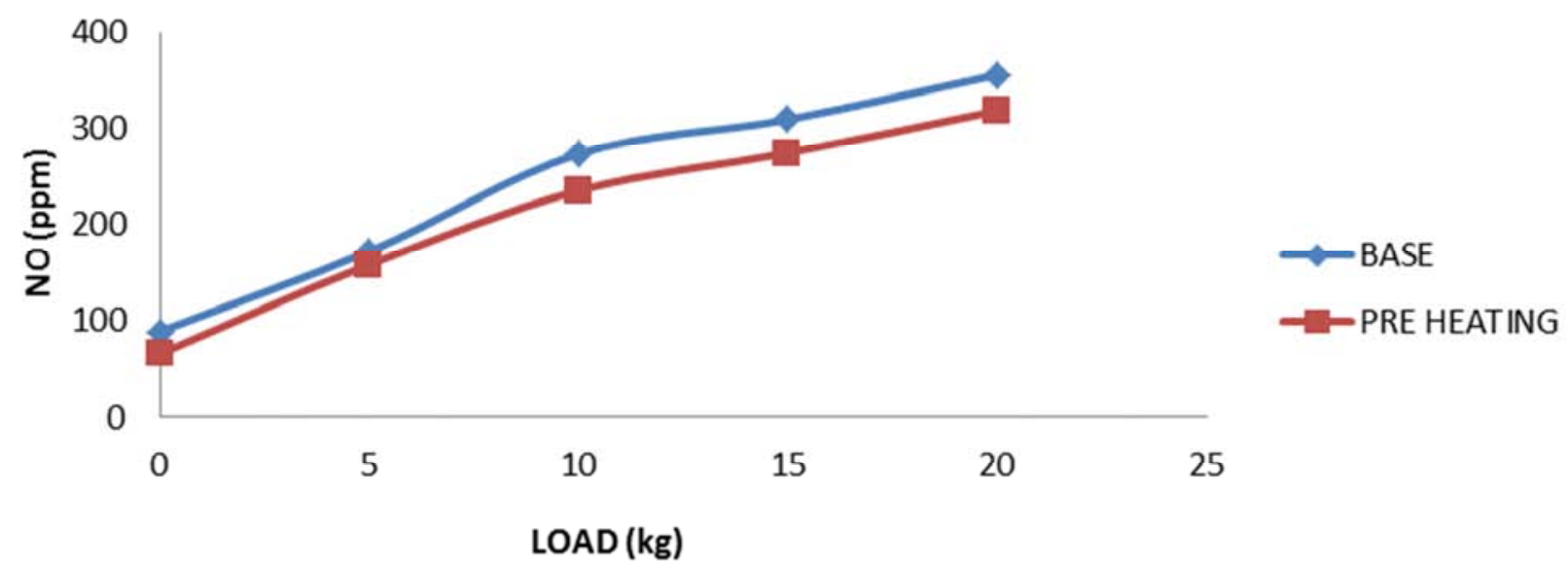

Figure 14. Load Vs Nitrous oxide emission (NO) for Pre Heating.

\section{LOAD Vs NOx}

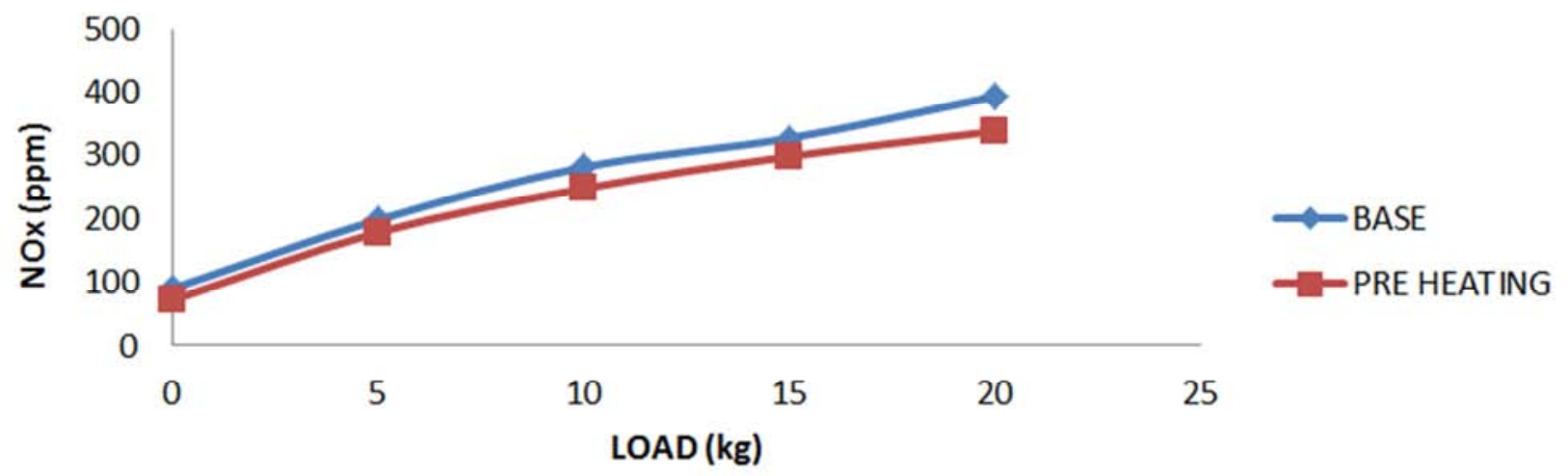

Figure 15. Load Vs NOx emission for Pre Heating.

Figure 12 and 13 shows that by pre heating the $\mathrm{CO}$ and $\mathrm{CO}_{2}$ formation are found to be increased when compard to base line data.

Fig. 14 shows benefit of EGR in reducing $\mathrm{NO}_{\mathrm{X}}$ emission from diesel engine. The degree of reduction of $\mathrm{NO}_{\mathrm{X}}$ is high while pre heating at high temperature.

PERFORMANCE GRAPH FOR PRE HEATING WITH EGR 


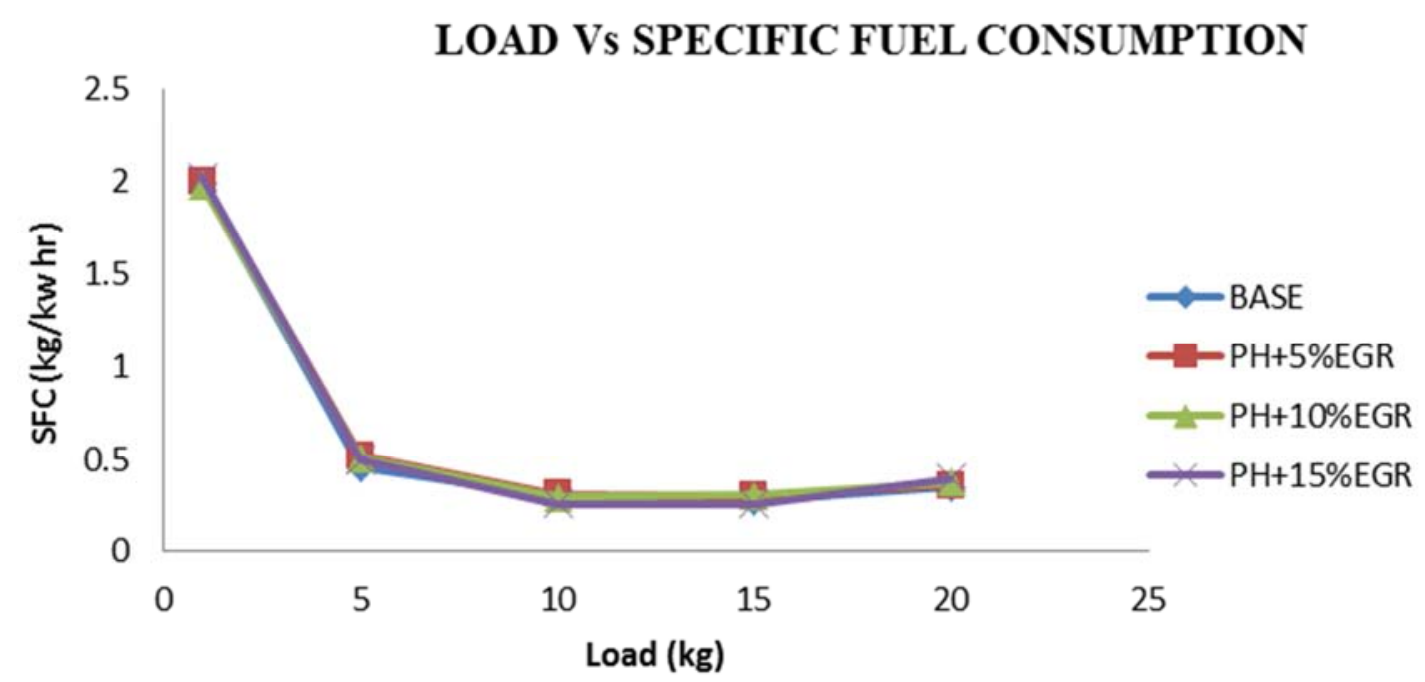

Figure 16. Load Vs Specific Fuel Consumption for pre heating with EGR.

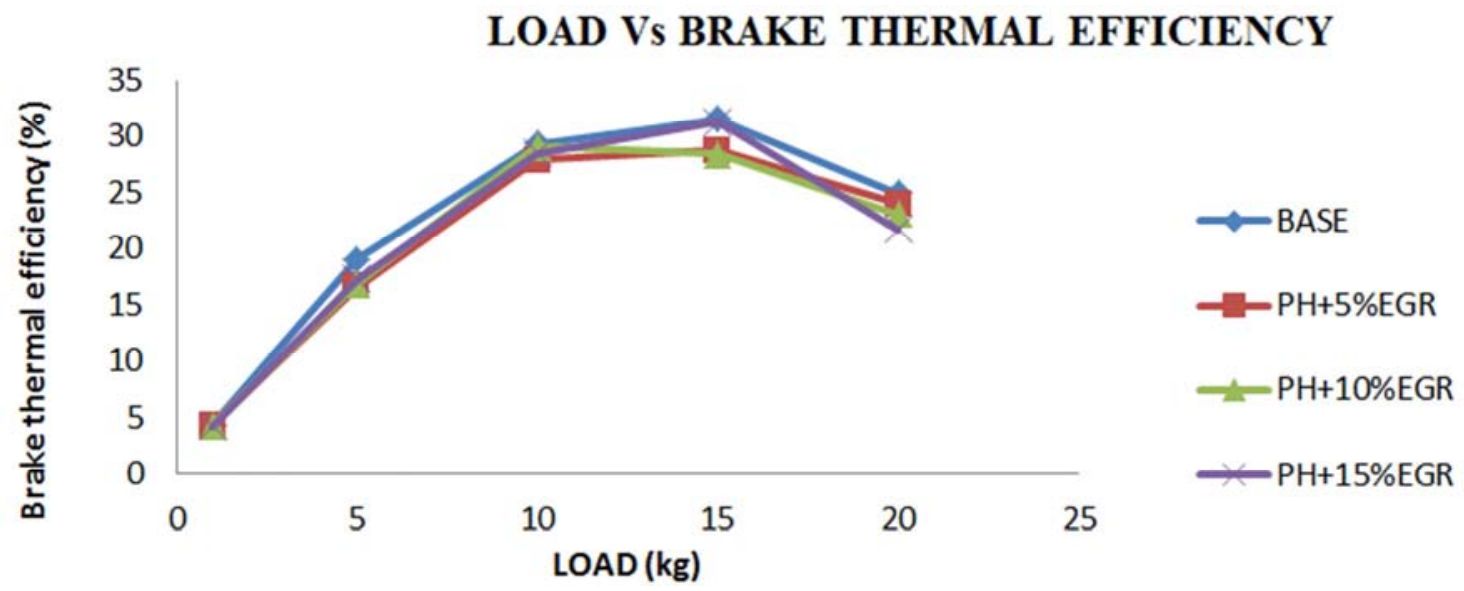

Figure 17. Load Vs Brake Thermal Efficiency for Pre Heating with EGR.

\section{LOAD Vs $\eta$ COMBUSTION}

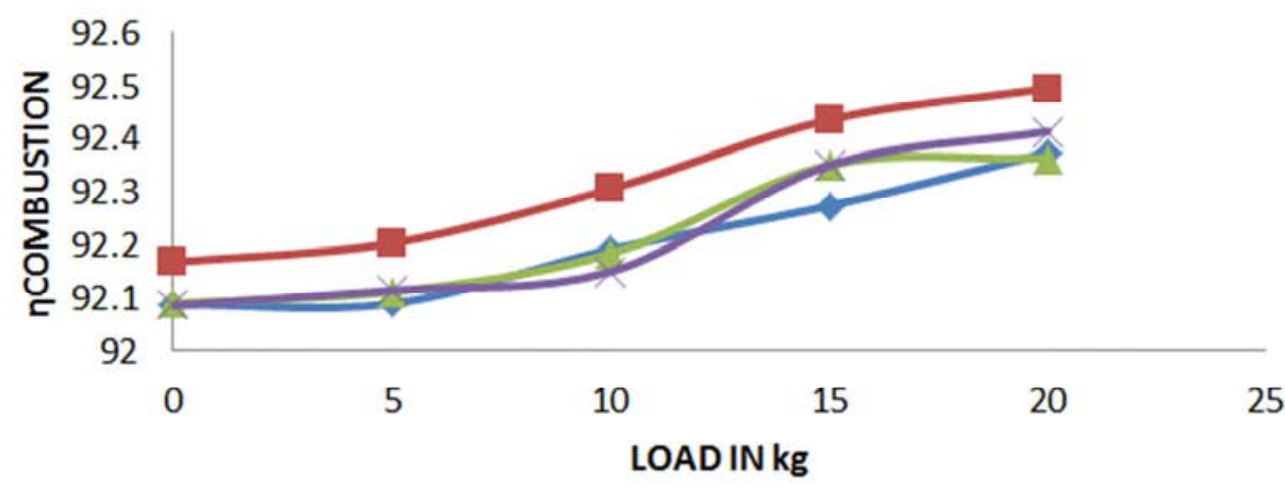

Figure 18. Load VS Combustion efficiency Efficiency for Pre Heating with EGR.

Figure 16 represents comparison of specific fuel consumption with load for pre heating with EGR and base line data. The brake specific fuel consumption is found to be not so much variation with base line data.

Figure 17 shows that when the load increased the thermal efficiency is found to be decreased for all pre heating with EGR percentage.
Figure 18 represents variation of combustion efficiency with engine load for different EGR percentage. The combustion efficiency is found to be high for all loads when using pre heating with $5 \% \mathrm{EGR}$. when compared to base line data Pre heating with $10 \%$ and $15 \%$ EGR gives high combustion efficiency at $15 \mathrm{~kg}$ load condition.

EMISSION GRAPH FOR PRE HEATING WITH EGR 

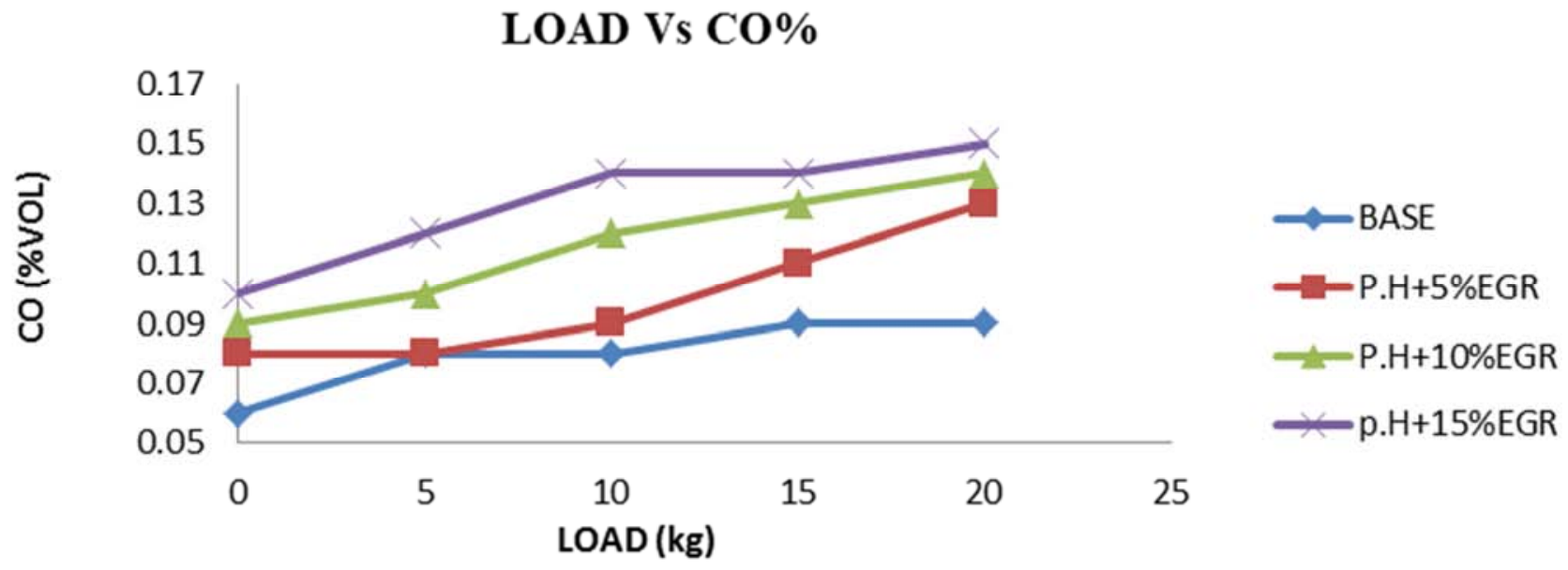

Figure 19. Load Vs Carbon monoxide emission (CO) for Pre Heating with EGR.

\section{LOAD Vs CO2\%}
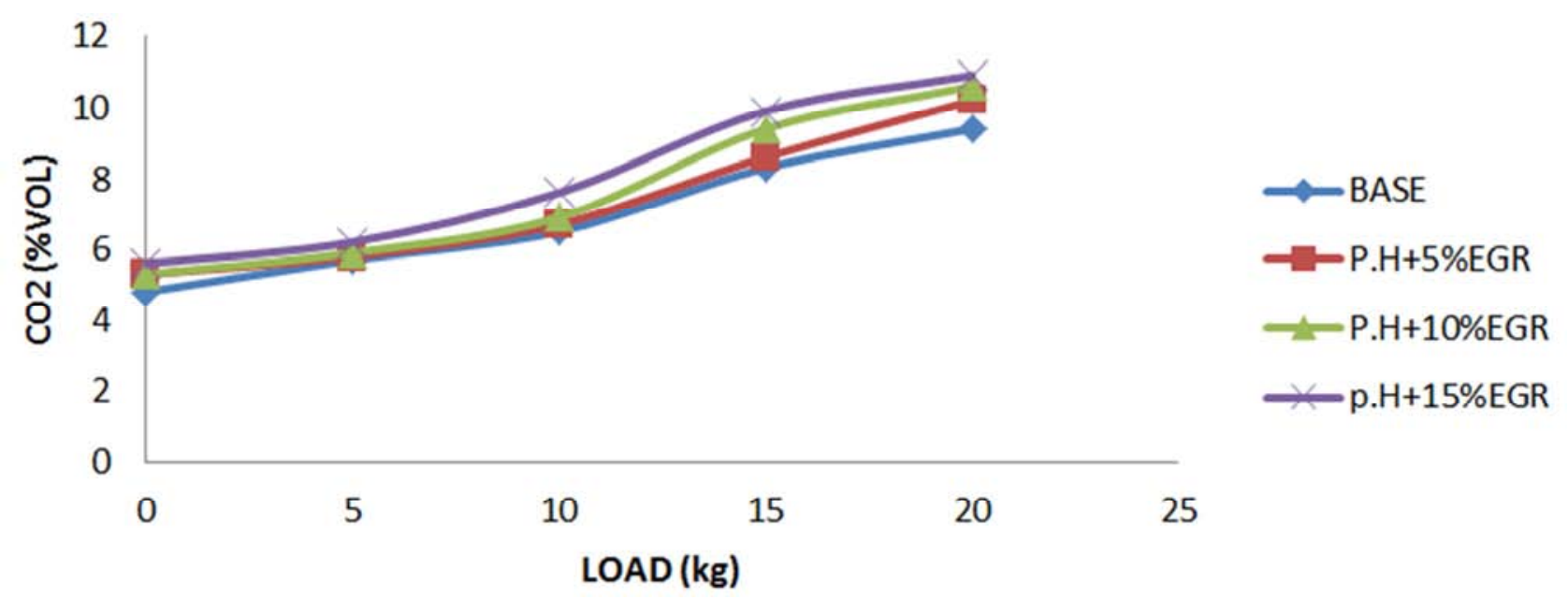

Figure 20. Load VS Carbon dioxide emission $\left(\mathrm{CO}_{2}\right)$ for Pre Heating with EGR.

\section{LOAD Vs NO}
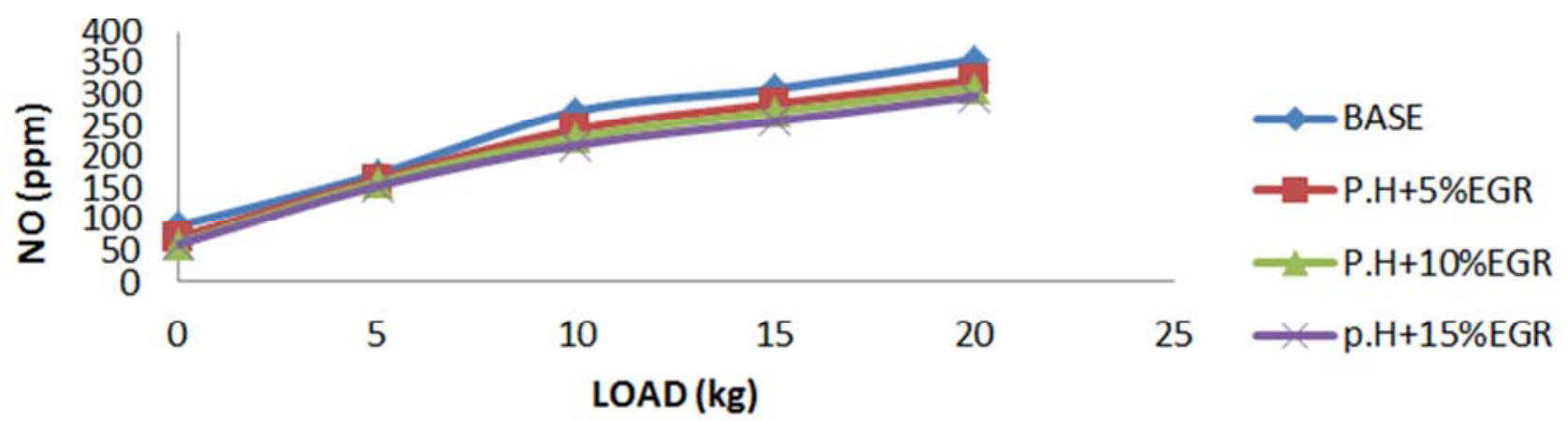

Figure 21. Load Vs Nitrous oxide emission (NO) for Pre Heating with EGR. 


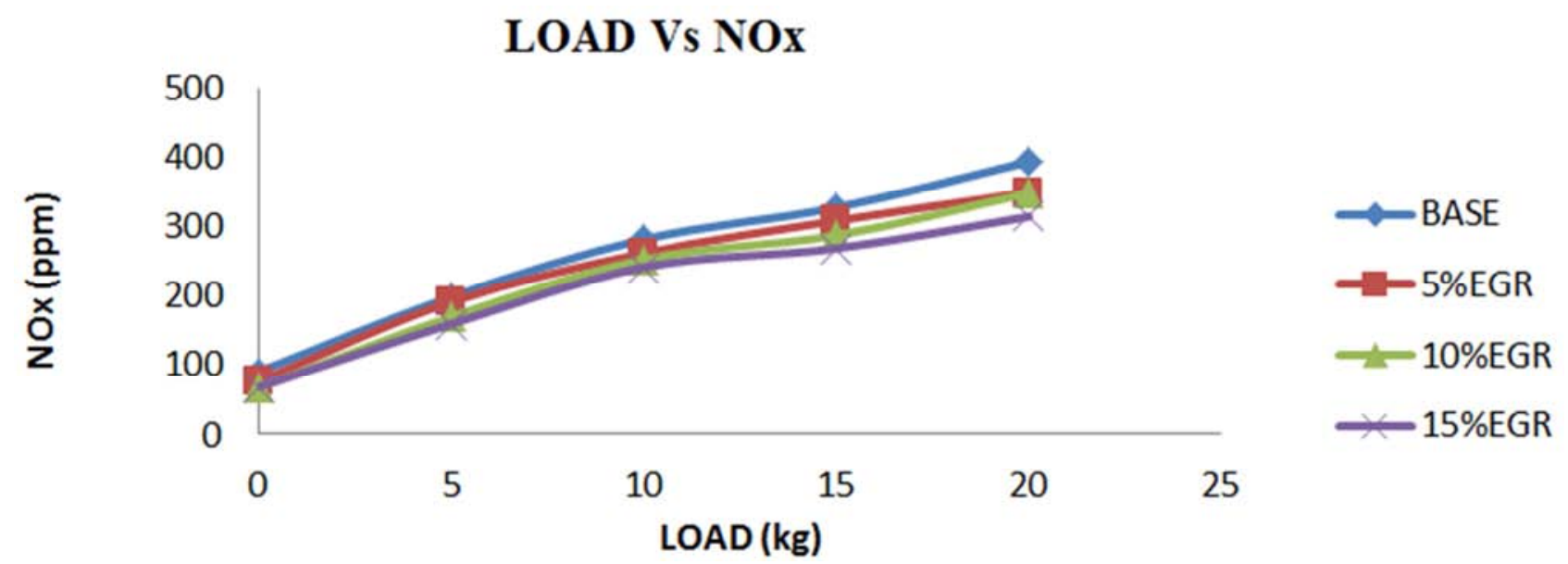

Figure 22. Load Vs NOx emission for Pre Heating with EGR.

Figure 18 and 19 shows by pre heating witg EGR the CO and $\mathrm{CO}_{2}$ formation are found to be increased when compard to base line data. Fig. 21 shows benefit of EGR in reducing $\mathrm{NO}_{\mathrm{X}}$ emission from diesel engine. The degree of reduction of $\mathrm{NO}_{\mathrm{X}}$ is high while pre heating with EGR at high rate.

Comparison of Results

The performance and emission results are compared for pre heating of the inlet air, exhaust gas recirculation and combined effect of pre heating of the inlet with exhaust gas recirculation are tabulated for engine operated at full Load condition are shown in below. Here carbon dioxide and carbon monoxide are increased with EGR, pre heating, EGR with pre heating. The increase in $\mathrm{CO}$ and $\mathrm{CO}_{2}$ emissions can be reduced by adopting exhaust after-treatment techniques, such as diesel oxidation catalysts and soot traps.

Performance Comparisons

Table 3. Performance comparisons.

\begin{tabular}{|c|c|c|c|c|c|c|c|c|}
\hline \multirow{3}{*}{ Performance parameter } & \multirow{3}{*}{ BASE engine } & \multicolumn{7}{|c|}{ Modified engine } \\
\hline & & \multirow{2}{*}{ P.H } & \multicolumn{3}{|l|}{ EGR } & \multicolumn{3}{|c|}{ P.H+EGR } \\
\hline & & & $5 \%$ & $10 \%$ & $15 \%$ & $5 \%$ & $10 \%$ & $15 \%$ \\
\hline Thermal Efficiency (\%) & 24.91 & 23.32 & 25.83 & 24.45 & 23.0 & 23.9 & 23.06 & 23.5 \\
\hline Specific Fuel Consumption (kg/kW-hr) & 0.344 & 0.364 & 0.331 & 0.350 & 0.44 & 0.357 & 0.37 & 0.36 \\
\hline
\end{tabular}

The comparison of thermal efficiency and SFC for all data sets using EGR, pre heating, EGR with pre heating and baseline data are shown in below table 4. The thermal efficiency is found to have slightly increased when using $5 \%$ EGR. At full Loads, the Thermal efficiency is affected by others like pre heating, EGR and EGR with pre heating. In higher Loads the exhaust gas has higher amount of $\mathrm{CO}_{2}$, which reduces maximum temperature in combustion chamber along with oxygen availability therefore re-burning of Hydro
Carbon is not significant, so that the reduction in thermal efficiencies are observed for other cases. However, at higher engine Loads; SFC with 5\% EGR is almost similar to that of without EGR.

By considering the other factors is observed that at higher Loads the amount of fuel supplied to the cylinder is increased at higher rate and oxygen available for combustion gets reduced. Thus, air fuel ratio is changed and this increases the SFC.

Emission Comparisons

Table 4. Emission comparisons.

\begin{tabular}{|c|c|c|c|c|c|c|c|c|}
\hline \multirow{3}{*}{ Performance parameter } & \multirow{3}{*}{ BASE engine } & \multicolumn{7}{|c|}{ Modified engine } \\
\hline & & \multirow{2}{*}{ P.H } & \multicolumn{3}{|l|}{ EGR } & \multicolumn{3}{|c|}{ P.H+EGR } \\
\hline & & & $5 \%$ & $10 \%$ & $15 \%$ & $5 \%$ & $10 \%$ & $15 \%$ \\
\hline $\mathrm{NO}_{\mathrm{X}}(\mathrm{ppm})$ & 393 & 338 & 341 & 352 & 317 & 349 & 348 & 314 \\
\hline NO (ppm) & 355 & 318 & 328 & 318 & 309 & 323 & 311 & 307 \\
\hline $\mathrm{CO}(\% \mathrm{vol})$ & 0.09 & 0.13 & 0.13 & 0.13 & 0.13 & 0.13 & 0.14 & 0.15 \\
\hline $\mathrm{CO}_{2}(\% \mathrm{vol})$ & 9.4 & 10.2 & 9.8 & 10.2 & 10.6 & 10.2 & 10.6 & 10.9 \\
\hline$\eta_{\text {combustion }}(\%)$ & 92.37 & 92.38 & 92.33 & 92.37 & 92.3 & 92.4 & 92.36 & 92.4 \\
\hline
\end{tabular}

Table 4 shows the main benefit of EGR in reducing NOx emissions from diesel engine. The degree of reduction in NOx at higher Loads is higher. The reasons for reduction in NOx emissions using EGR in diesel engines are reduced oxygen concentration and decreased flame temperatures in the combustible mixture.

\section{Conclusion}

The following conclusions are made based on experimental results.

- The thermal efficiency is decreased for EGR, pre 
heating, EGR with pre heating compared to base engine due to reduction in availability of oxygen concentration in the combustion chamber.

- The specific fuel consumption for EGR, pre heating, EGR with pre heating are increased compared to base engine due to the reduction in oxygen content leads to reduced the air fuel ratio hence the SFC is increased.

- For all cases like EGR, pre heating, EGR with pre heating the NOx emissions is reduced. The reasons for reduction in NOx emissions in diesel engines are due to reduced oxygen concentration and decreased flame temperatures in the combustible mixture.

- Exhaust after-treatment techniques will be adopted to reduce the $\mathrm{CO}$ and $\mathrm{CO}_{2}$ emission.

\section{References}

[1] Ming Zheng, Graham T. Reader, J. Gary Hawley, 2004, "Diesel engine exhaust gas recirculation-a review on advanced and novel concepts" Energy Conversion and Management 45, 883-900.

[2] Deepak Agarwal, Shrawan Kumar Singh, Avinash Kumar Agarwal, 2011, "Effect of Exhaust Gas Recirculation (EGR) on performance, emissions, deposits and durability of a constant speed compression ignition engine" Applied Energy 88, 2900-2907.

[3] D. T. Hountalasa, G. C. Mavropoulosa, K. B. Binder, 2008, "Effect of exhaust gas recirculation (EGR) temperature for various EGR rates on heavy duty DI diesel engine performance and emissions" Energy 33, 272-283.

[4] S. Periyasamy, T. Alwarsamy and G. sivakumar, 2011 "Experimental investigation of performance and emission characteristics by different exhaust gas re circulation methods used in diesel engine" international conference on thermal energy and environment.

[5] M. Ghazikhani, M. E. Feyz, A. Joharchi, 2010, "Experimental investigation of the Exhaust Gas Recirculation effects on irreversibility and Brake Specific Fuel Consumption of indirect injection diesel engines" Applied Thermal Engineering 30, 1711-1718.

[6] Alain Maiboom, Xavier Tauzia, 2008, "Experimental study of various effects of exhaust gas recirculation (EGR) on combustion and emissions of an automotive direct injection diesel engine" Energy 33, 22-34.

[7] Ralf Moosb, Burkhard Reetmeyer, Armin H"urland, Carsten Plog, 2006 "Sensor for directly determining the exhaust gas recirculation rate-EGR sensor" Sensors and Actuators B 119, $57-63$.

[8] G. H. Abd-Alla, 2002 "Using exhaust gas recirculation in internal combustion engines: a review" Energy Conversion and Management 43, 1027-1042.

[9] Probir Kumar Bose, Dines Maji, 2009, “An experimental investigation on engine performance and emissions of a single cylinder diesel engine using hydrogen as inducted fuel and diesel as injected fuel with exhaust gas recirculation" international journel of hydrogen energy $34,4847-4854$.
Dhanasekaran, 2008, “An experimental investigation on hydrogen as a dual fuel for diesel engine system with exhaust gas recirculation technique" Renewable Energy 33, 422-427.

[11] Tsolakisa, A. Megaritis, D. Ya, 2008, “Application of exhaust gas fuel reforming in diesel and homogeneouscharge compression ignition (HCCI) engines fuelled with biofuels" Energy 33, 462-470.

[12] Ruijun Zhu, Xibin Wang, Haiyan Miao, Xiaofeng Yang, Zuohua Huang, 2011, "Effect of dimethoxy-methane and exhaust gas recirculation on combustion and emission characteristics of a direct injection diesel engine" Fuel 90, 1731-1737.

[13] H. E. Saleh, 2009, "Effect of exhaust gas recirculation on diesel engine nitrogen oxide reduction operating with jojoba methyl ester" Renewable Energy 34, 2178-2186.

[14] Tie Li, Masaru Suzuki, Hideyuki Ogawa, 2009, "Effects of ethyl tert-butyl ether addition to diesel fuel on characteristics of combustion and exhaust emissions of diesel engines" Fuel $88,2017-2024$

[15] A. Tsolakis, A. Megariti, M. L. Wyszynski, K. Theinnoi, 2007, "Engine performance and emissions of a diesel engine operating on diesel-RME (rapeseed methyl ester) blends with EGR (exhaust gas recirculation)” Energy 32, 2072-2080

[16] J. P. Holman., 2007, "Experimental Methods for Engineers" Tata McGraw-Hill Company.

[17] A. Tsolakis, A. Megariti, M. L. Wyszynski, K. Theinnoi, 2007, "Engine performance and emissions of a diesel engine operating on diesel-RME (rapeseed methyl ester) blends with EGR (exhaust gas recirculation)" Energy 32, 2072-2080.

[18] Nidal H. Abu-Hamdeh, 2003, "Effect of cooling the recalculated exhausts gases on diesel engine emissions" Energy Conversion and Management 44, 3113-3124.

[19] John Heywood., 1989, "Internal Combustion Engine Fundamentals" Tata McGraw-Hill Company.

[20] M. S. Abd-Elhady, T. Zornek, M. R. Malayeri, S. Balestrino, P. G. Szymkowicz, H. Müller-Steinhagen, 2011, "Influence of gas velocity on particulate fouling of exhaust gas recirculation coolers" International Journal of Heat and Mass Transfer 54, 838-846.

[21] Mhia Md. Zaglul Shahadat, Md. Nurun Nabi and Md. Shamim Akhter, "Diesel NOx reduction by preheating inlet air", (ICME2005) 28- 30 December 2005, Dhaka, Bangladesh.

[22] Dae Hee Lee,Jun Sik Lee, Jae Suk Park, "Effects of secondary combustion on efficiencies and emission reduction in the diesel engine exhaust heat recovery system", Applied Energy 87 (2010) 1716-1721.

[23] Asok K. Sen, Sudhir K. Ash, Bin Huang, "Effect of exhaust gas recirculation on the cycle-to-cycle variations in a natural gas spark ignition engine", Applied Thermal Engineering 31 (2011) $2247 \mathrm{e} 2253$.

[24] M. Ghazikhani, M. E. Feyz, A. Joharchi, 2010, "Experimental investigation of the Exhaust Gas Recirculation effects on irreversibility and Brake Specific Fuel Consumption of indirect injection diesel engines" Applied Thermal Engineering 30, 1711-1718.

[10] N. Saravanan, G. Nagarajan, K. M. Kalaiselvan, C. 